\title{
一般口演 8
}

\section{骨格性 III級不正咬合患者における外科的矯正治療が 咀嚼機能に及ぼす影響}

\author{
Influence of surgical orthodontic treatment on masticatory function \\ in patients with skeletal Class III
}

\author{
$\bigcirc$ 窪田健司 ${ }^{1)}$, 八木孝和 ${ }^{2}$, 友成 博 $^{1)}$, 上原沢子 ${ }^{1)}$, 池森宇泰 ${ }^{1)}$, 宮脇正一 ${ }^{1)}$ \\ Takeshi Kubota $^{1)}$, Takakazu Yagi ${ }^{2}$, Hiroshi Tomonari ${ }^{1)}$, Sawako Uehara ${ }^{1)}$ \\ Takahiro Ikemori ${ }^{1}$, Shouichi Miyawaki ${ }^{1)}$ \\ 1) 鹿児島大学大学院医歯学総合研究科歯科矯正学分野 \\ 2) 鹿児島大学医学部・歯学部附属病院歯科センター矯正歯科 \\ ${ }^{1)}$ Department of Orthodontics, Kagoshima University Graduate School of Medical and Dental Sciences \\ ${ }^{2)}$ Department of Orthodontics, Kagoshima University, Medical and Dental Hospital
}

\section{I. 目的}

骨格性而級不正咬合患者の下顎運動に関して，外科的 矯正治療前後に扔ける下顎切歯部の最大開閉口経路の変 化を示した報告や，下顎頭部の運動に関して，外科的矯 正治療後に正常咬合者と類似の運動経路を示す報告 ${ }^{1)}$ は あるが，咀嚼中の下顎切歯部の運動経路について定量的 に調べた報告はない。

一方，骨格性 II 級不正咬合患者の咀嚼筋活動につい て，正常咬合者と異なるという報告や外科的矯正治療に より左右咀嚼筋の筋活動量のバランスが改善したとする 報告 ${ }^{2)}$ はあるが，下顎運動との同時記録を調べた報告 ${ }^{3)}$ は少ない。

今回，骨格性而級不正咬合患者における外科的矯正治 療前後の咀嚼中の下嚬運動の変化を調べた。また, 咬筋 と側頭筋の相対的な筋活動を評価し, その变化を, 初診 時と保定中で比較検討した.

\section{II. 方 法}

\section{1. 被験者}

鹿児島大学病院矯正歯科外来を受診し, 外科的矯正治 療の適用と診断され，前歯部反対咬合㧍よび臼歯関係吕 級を示す骨格性下顎前突症患者 (女性 14 名, 平均年齢 $22.6 \pm 3.4$ 歳) を対象とした。
同大学口腔外科にて両側の下顎枝矢状骨切術（SSRO） を行った。いずれの症例も外科的矯正治療後半年以上経 過しており，顎間関係は良好で咬合も安定していた。

唇顎口蓋裂をはじめとする先天異常や, 顎関節症状が 認められるものは対象から除外した。

\section{2. 資料の採得と分析}

1) 側面頭部 X 線規格写真分析

初診時㧍よび保定中に撮影した患者の側面頭部 X 線 規格写真から透写図を作成し, 角度計測項目として, SNA, SNB, ANB, facial angle, Y-axis, gonial angle の項目，距離計測項目として，Wits 抢よびセットバッ ク量を計測し，平均値と標準偏差を算出した。

2) 下顎運動の記録と解析

下顎運動の記録は， 3 次元 6 自由度の下顎運動解析 装置（ナソヘキサグラフ，GC，東京）を用いて行った. 検查用グミゼリーを片側で咀嚼させ, 最初の 1 サイクル を除いた 5 サイクルの平均下顎運動パターンを, 初診時 と保定時で比較した。咀嚼サイクルの計測項目は, 前頭 面観に扔いて, 咬頭嵌合位から $2.0 \mathrm{~mm}$ 下方に水平基準 線を設定し，各計測項目 ${ }^{4)}$ を算出した。(図)

3）筋電図の記録と解析

筋電図解析は, 下顎運動と同期して選択した 5 サイク ルの咬筋と側頭筋の平均筋活動量を算出した。また，咬 筋と側頭筋の筋活動量を相対的に評価するため, 以下の 


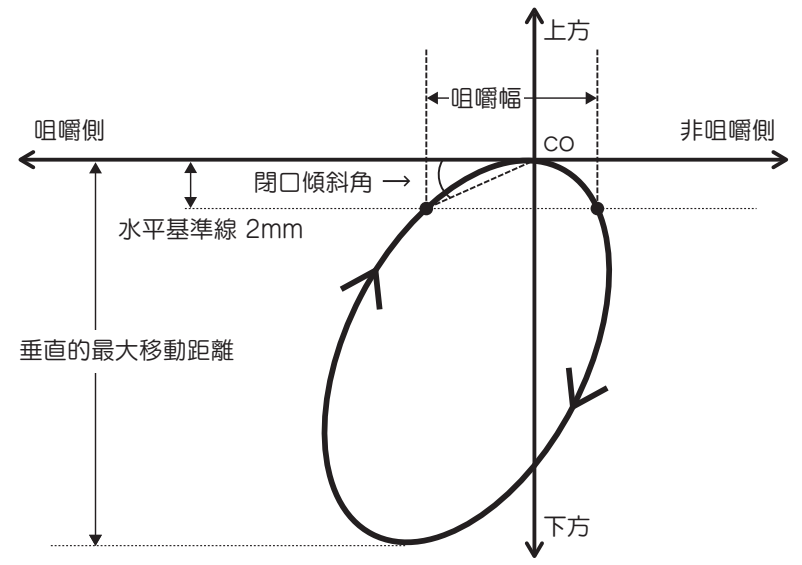

図下顎運動経路（前頭面観）の分析項目

ように活動性指数 ${ }^{5)}$ を算出した。

活動性指数 $(\%)=[$ (咬筋の平均筋活動量－側頭筋の平 均筋活動量 $) /($ 咬筋の平均筋活動量 + 側頭筋の平均筋 活動量) $] \times 100$

4 ) 統計解析

治療前後の顎顔面形態分析, 下顎運動および筋電困の 比較は, paired t-testを用いた。

\section{III. 結果及び考察}

治療前後における骨格系の変化は，七ットバック量は 平均 $9.4 \pm 1.7 \mathrm{~mm}$ であり, $\mathrm{ANB}$ は $-2.4 \pm 2.0^{\circ}$ から +2.1 $\pm 1.5^{\circ}$ に変化した.

咀嚼運動時の下顎運動経路の変化は治療後に閉口傾 斜角が有意に小さくなり，咀嚼幅が有意に大きくなっ たが, 垂直的最大移動距離は変化しなかった。下顎骨 のセットバックにより, 閉口傾斜角および咀嚼幅は影 響を受けるが，習慣性咀嚼時の垂直的最大移動距離は， Miyawaki らが食物の大きさに依存するとした報告 ${ }^{6)}$ と 一致した。

一方, 下顎頭の運動について, Wang らは, 治療前に 正常咬合者と異なる軌跡を示していたにもかかわらず，

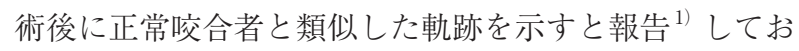

り，下顎切歯部の軌跡を調べた今回の研究でも，治療 後の下顎切歯部の下顎運動経路の咀嚼幅が広くなってお り，過去の報告と一致した。筋電困解析では，治療前後 の咬筋と側頭筋の筋活動量を相対的に比較すると, 治療 前は側頭筋優位から, 治療後, 咬筋優位に変化した。

以上より，外科的矯正治療により形態的，審美的に改 善されるともに，下顎運動や咀嚼筋活動が改善すること が示唆された.

\section{N. 文 献}

1) Wang D, Fu H, Zeng R, et al. Changes of mandibular movement tracings after the correction of mandibular protrusion by bilateral sagittal split ramus osteotomy. J Oral Maxillofac Surg 2009; 67(10): 2238-2244.

2 ) Di Palma E, Gasparini G, Pelo S, et al. Activities of masticatory muscles in patients after orthognathic surgery. J Craniomaxillofac Surg 2009; 37(7): 417-420.

3 ) Nakata Y, Ueda HM, Kato M, et al. Changes in stomatognathic function induced by orthognathic surgery in patients with mandibular prognathism. J Oral Maxillofac Surg 2007; 65(3): 444-451.

4 ) Komagamine Y, Kanazawa M, Minakuchi S, et al. Association between masticatory performance using a colour-changeable chewing gum and jaw movement. J Oral Rehabil 2011; 38(8): 555-563.

5 ) Visser A, McCarroll RS, Naeije M. Masticatory muscle activity in different jaw relations during submaximal clenching efforts. J Dent Res 1992; 71(2): 372-379.

6 ) Miyawaki S, Ohkochi N, Kawakami T, et al. Effect of food size on the movement of the mandibular first molars and condyles during deliberate unilateral mastication in humans. J Dent Res 2000; 79(7): 1525-1531. 